\title{
Study of Slow Sand Filtration in Removing Total Coliforms and E.Coli
}

\author{
Ekha Yogafanny ${ }^{1)}$; Stephan Fuchs ${ }^{2)}$; and Ursula Obst ${ }^{3)}$ \\ ${ }^{1)}$ Dept. Environmental Engineering, Faculty of Mineral Technology, \\ University of Pembangunan Nasional Yogyakarta, Indonesia \\ ${ }^{2)}$ Institut für Wasser und Gewässerentwicklung (IWG), Karlsruher Institut für Technologie (KIT), Germany \\ ${ }^{3)}$ Institut für Funktionelle Grenzflächen (IFG), Karlsruher Institut für Technologie (KIT), Germany
}

\begin{abstract}
This study was aimed to evaluate the performance of SSF in removing bacteria (Total Coliforms and E. Coli) in regard to grain size distribution and grain shape intermittently. Two methodological approaches used in this reasearch were literature review and laboratory work. Bacteria removal was analyzed considering two different filter media (Rhine sand-spherical shape and Lava sand-angular shape) with three different grain size distributions. The best performance was attained by filter column F4 which consisted of Lava sand and had the configuration C2 $(d 10=0.07 \mathrm{~mm} ; \mathrm{Cu}=$ 4.2). This filter column achieved 4.7log-units removal of Total Coliforms and 5.Olog-units removal of E. coli. The results show that a smaller grain size and an angular shape of sand grain lead to an increase in bacteria removal.
\end{abstract}

Keywords: Slow Sand Filtration, Bacteria Removal, Grain Size Distribution, Grain Shape

\section{INTRODUCTION}

Water is the most essential resource for everyone in the world, especially for drinking water and sanitation. Nowadays, many people still do not have a safe and sustainable access neither to drinking water nor to sanitation (WHO \& UNICEF, 2010). Indonesia is one of the Southeast Asian Countries and has some regions where the water cannot be easily accessed by people. One of these regions is Gunung Kidul District, Yogyakarta Special Province. This region is located in the southern part of Yogyakarta Special Province. Most of Gunung Kidul District areas are situated in a karst landform zone. Gunung Kidul karst area occupies $65 \%$ of the Western Gunung Sewu (Thousand Hills) karst (Haryono \& Day, 2004). The special feature of karst formation leads people living in this area suffer from water scarcity, mainly during the dry season. Karst formations consist of carbonate and gypsum rock that have a high solubility rate and also high infiltration rate. As a result, this region undergoes an extreme water shortage especially during the dry seasons. This situation could be enhanced by pumping up the water from underground to the surface (Nestmann et al., 2011). Since the water quality is not good, the water in the surface should be treated first before its distribution. Slow Sand Filtration (SSF) was selected as the most appropriate technology considering several factors including regulatory requirements, cost, and operation. 
The aim of this study is to evaluate the performance of SSF regarding bacteria removal considering some variables such as grain size distribution and grain shape. Furthermore, to achieve the main objective of this research, specific objectives need to be accomplished and are defined as follows:

1. To ascertain whether SSF might be also used to remove (reduce) the bacteria content from the raw water.

2. To analyze the effect of grain size distribution and grain shape on filter performance in regard to bacteria removal.

\section{RESEARCH METHODS}

Laboratory tests were conducted in filter columns. The experimental setup consisted of 5 columns with a diameter of $5.2 \mathrm{~cm}$ and a height of $120 \mathrm{~cm}$ containing a layer of sand supported by a layer of gravel. Each column has a valve at the bottom outlet connected with a hose and a clamp. The clamp was applied in each column in order to easily be able to control the filtration velocity at the outlet. The bacteria removal was analyzed based on three sand filter configurations within two different sand types and under intermittent operation mode. These three configurations of sand filter were $\mathrm{C} 1$ $(\mathrm{d} 10=0.13 \mathrm{~mm}, \mathrm{Cu}=3.7), \mathrm{C} 2(\mathrm{~d} 10=0.07 \mathrm{~mm}, \mathrm{Cu}=4.2)$, and configuration of control filter $(\mathrm{d} 10$ $=0.2 \mathrm{~mm}, \mathrm{Cu}=2.1$ ) . in the beginning of this experiment, all filter columns were operated under HLR $0.1-0.2 \mathrm{~m} / \mathrm{h}$ and at the end, those columns were operated with HLR $0.03 \mathrm{~m} / \mathrm{h}$.

These sands with their configurations were poured into five filter columns. A gravel layer $(5 \mathrm{~cm})$ was placed at the bottom of each column, supporting the sand bed $(50 \mathrm{~cm})$, in order to avoid the sand flowing out of the filter that can be seen in Figure 1. An additional gravel layer $(5 \mathrm{~cm})$ was placed upon the surface of the sand bed to reduce or avoid the disturbance of surface layer of sand when the water was introduced into the column. The columns were constructed as follows: filter columns F1 and F2 followed the configuration $\mathrm{C} 1$, filter columns F3 and F4 followed the configuration $\mathrm{C} 2$, and filter column F5 was filled with sand directly from the nature. Filter columns F1, F3, and F5 were filled with Rhine sand while filter columns F2 and F4 were filled with Lava sand. 


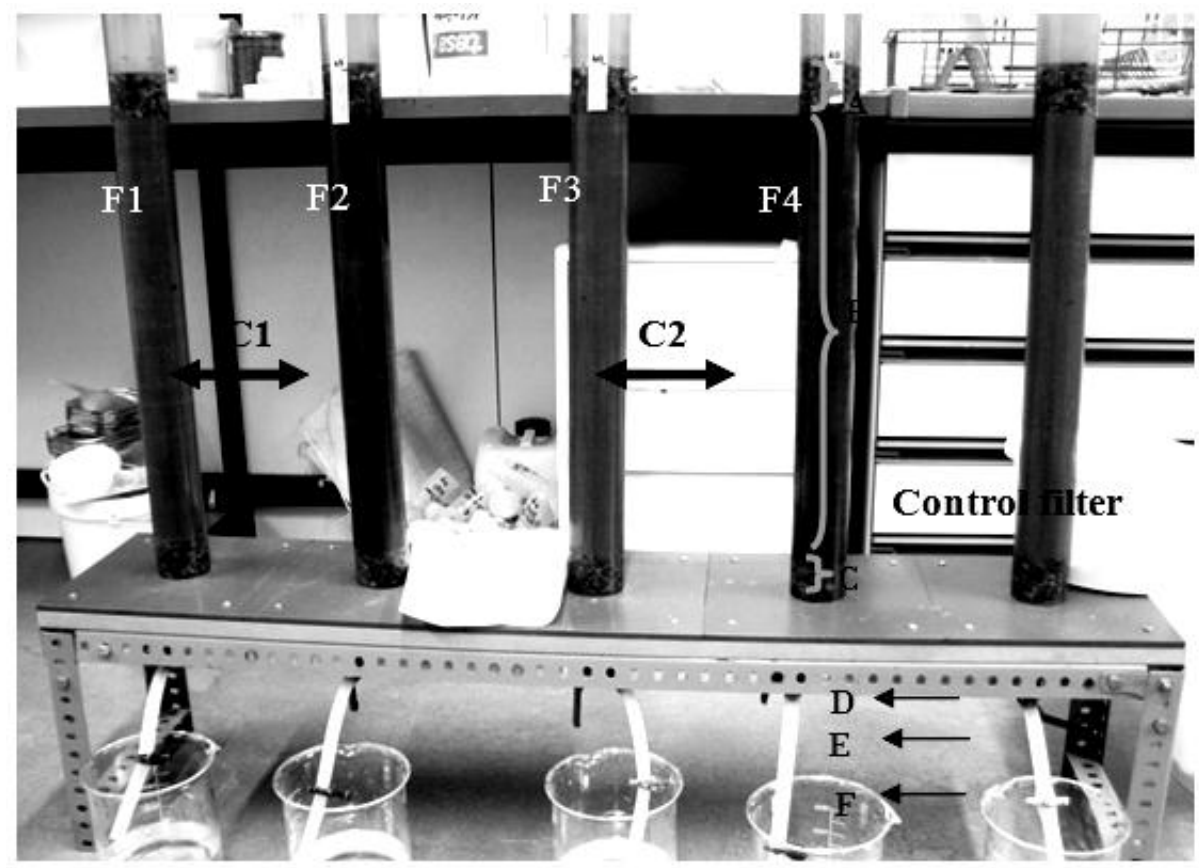

A \& C: Gravel layer; B: sand bed; D: valve; E: hose; F: clamp

Figure 1. Experimental setup

During column construction, the sand characteristics i.e. porosity, permeability, and sand surface area were calculated by some equations.

\begin{tabular}{|lll|}
\hline \multicolumn{1}{|c}{ Porosity } & \multicolumn{1}{c|}{ Permeability } & \multicolumn{1}{c|}{ Sand surface area } \\
$\mathrm{n}=\mathrm{V}_{\text {voids }} / \mathrm{V}_{\text {total }}$ & $k_{T}=(a L / A t) \log (h / h f)$ & $\mathrm{A}_{\mathrm{s}}=\left(6000 / \mathrm{d}_{\mathrm{s}}\right)(1-\mathrm{p})$ \\
$\mathrm{n}=1-\left(\gamma_{\mathrm{d}} /\left(\right.\right.$ Gs. $\left.\left.\gamma_{\mathrm{w}}\right)\right)$ & $\mathrm{d}_{\mathrm{s}}=\mathrm{d}_{10}(1+2 \log \mathrm{Cu})$ \\
$\mathrm{Gs}=\gamma_{\mathrm{d}} / \gamma_{\mathrm{w}}$ & $\mathrm{A}=\mathrm{As}\left(\pi \mathrm{d}^{2} / 4\right) .1$ \\
$\gamma_{\mathrm{d}}=\mathrm{Ws} / \mathrm{V}=\mathrm{Ws} /\left((\pi / 4) \mathrm{D}^{2} \mathrm{H}\right)$ & \\
\hline
\end{tabular}

where $\mathrm{n}$ is porosity, $\mathrm{V}_{\text {void }}$ or $\mathrm{Vv}$ is volume or the pore space, and $\mathrm{V}_{\text {total }}$ or $\mathrm{V}$ is the total volume of sample, $\gamma \mathrm{d}$ is the dry unit weight, Gs is the specific gravity, $\gamma \mathrm{w}$ is the water unit weight, Ws is the dry sample weight, $\mathrm{D}$ is the diameter of the filter column, and $\mathrm{H}$ is the sand bed height. For permeability, $a$ is the cross-sectional area of the standpipe, $A$ is the cross-sectional area of the specimen, $L$ is the length of the specimen, $h_{o}$ is the elevation above the datum of water in the standpipe at the beginning of the experiment $(\mathrm{t}=0)$, and $h f$ is the elevation above the datum of water in the standpipe at time t. For Sand surface area, As is specific surface area $\left(\mathrm{m}^{2} / \mathrm{m}^{3}\right)$, ds is the specific grain diameter, and $\mathrm{p}$ is porosity, $\mathrm{A}$ is the total sand surface area $\left(\mathrm{m}^{2}\right), \mathrm{d}$ is the inner diameter of the filter column, and 1 is the bed depth. 
Intermittent operation mode was applied in this experiment by feeding the columns with the raw water once in a day and five days in a week. By doing so, pause periods of a minimum of 24 hours could be achieved in this time interval. Water samples were taken from influent and effluent so that the microbiological test could be conducted to measure the bacteria concentration in the water.

Evaluating the bacteria removal is one of the main objectives in this resaerch. To evaluate the bacteria removal, the concentration of bacteria from influent and effluent in every time feeding must be known. The colilert-18 was used to measure the bacteria concentration from influent and effluent water. The colilert-18 measurement was done every afternoon so that the result could be measured by the next day in the morning. The influent water was made by mixing the wastewater and the tap water with the dilution of 1:10. Colony forming units (CFU) per $100 \mathrm{ml}$ were calculated from the number of positive wells in the Quanti-Tray/2000 then multiplied by the dilution factor (if any). The bacteria concentrations were then transformed to the $\log 10$-units using the equation below.

$\log$ reduction $=\log (\mathrm{cfu} / 100 \mathrm{ml}) \inf -\log (\mathrm{cfu} / 100 \mathrm{ml})$ eff

\section{RESULT AND DISCUSSION}

\section{a. Effect of grain size distribution on bacteria removal}

The overall performance of these columns regarding bacteria removal was good achieving $1.6-4.7$ log-units or 97.7 - 99.998\% removal of total coliforms and 1.6 - 5 log-units or $97.6-99.999 \%$ removal of E. coli. The best performance with the consistent result was attained by filter column F4 which consisted of Lava sand and had the configuration $\mathrm{C} 2(\mathrm{~d} 10=0.07 \mathrm{~mm}$ and $\mathrm{Cu}=4.2)$.

Ausland et al. (2002), Langenbach et al. (2009), Bellamy et al. (1985a) and Bellamy et al. (1985b) found out that a decrease in grain size leads to an increase in treatment efficiency. From the results obtained in this study, these two indicator bacteria seem to follow the same trend, i.e. the highest bacteria removal corresponded to the finest grain size. The difference of bacteria removal becomes evident when configuration $\mathrm{C} 1$ and $\mathrm{C} 2$ are compared as can be seen in Figure 2. 


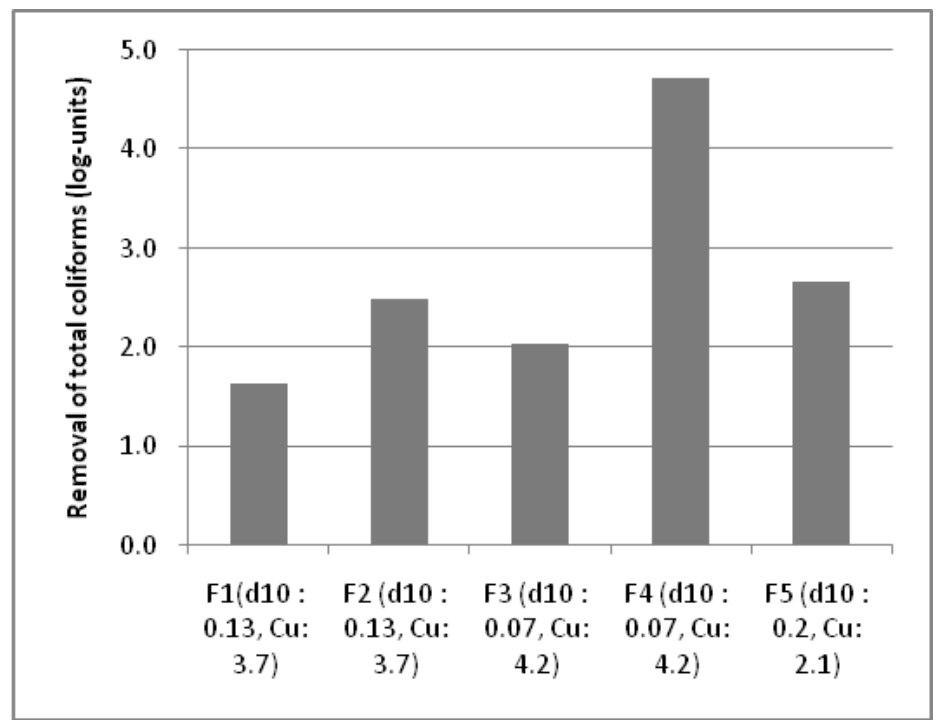

Figure 2. The removal of total coliforms bacteria in five filter columns

In the filter with Lava sand (F2 and F4), a higher removal of both total coliforms and E. coli was attained by filter column $\mathrm{F} 4$ that had sand with $\mathrm{d} 10$ of $0.07 \mathrm{~mm}$ and $\mathrm{Cu}$ of 4.2 . This trend was also found in the filters with the Rhine sand as sand type (F1 and F3). Filter column F3 (d10 of $0.07 \mathrm{~mm}$ and $\mathrm{Cu}$ of 4.2) appeared to have a better performance compared to filter column $\mathrm{F} 1$, achieving a higher log-removal. On the other hand, when comparing filter columns F1, F3, and F5 that had the same sand type (Rhine sand), filter column F5 (d10 $0.2 \mathrm{~mm}$ and $\mathrm{Cu} 2.1)$ achieved better results (2.7 log-units of both total coliforms and E. coli) compared to filter columns F1 and F3. It was expected that filter column F5 would show good removal efficiency as its media characteristics are within the recommended range $(\mathrm{d} 10=0.15-0.30 \mathrm{~mm}$ and $\mathrm{Cu}=<3)$. The performance of this column can be deemed as a control for the other column's performances.

Stevik et al. (2004) explained that adsorption is the most important mechanism in retaining bacteria compared to straining. An increase in sand surface area leads to an increase in adsorption spots on sand and biofilm attached to the sand grains. The results achieved in this study showed that indeed, finer sand or smaller grain sizes present a larger sand surface area compared to coarse sand and therefore provide more adhesion or adsorption spots.

\section{b. Effect of sand type (grain shape) on bacteria removal}

The results showed that not only the grain size distribution but also sand type (grain shape) played an important role in removing bacteria by slow sand filtration. Figure 2 until 4.3 depict the relationship between the bacteria removal (present only total coliforms, because the behavior of all 
filter columns for both total coliform and E. coli was the same) and the sand type considering that both filter columns have the same grain size distribution $(\mathrm{d} 10$ and $\mathrm{Cu})$. This comparison was made according to the configurations used in this experiment. There were two configuration applied i.e. configuration $\mathrm{C} 1$ (coarser; $\mathrm{d} 10=0.13 \mathrm{~mm}, \mathrm{Cu}=3.7$ ) and configuration $\mathrm{C} 2$ (finer; $\mathrm{d} 10=0.07 \mathrm{~mm}$, $\mathrm{Cu}=4.2)$.

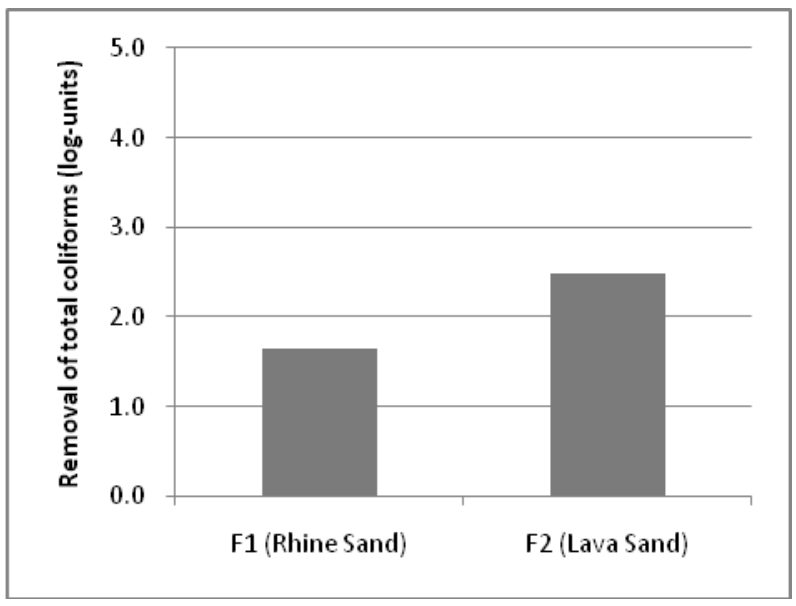

Figure 3. Removal of total coliform in configuration $\mathrm{C} 1$

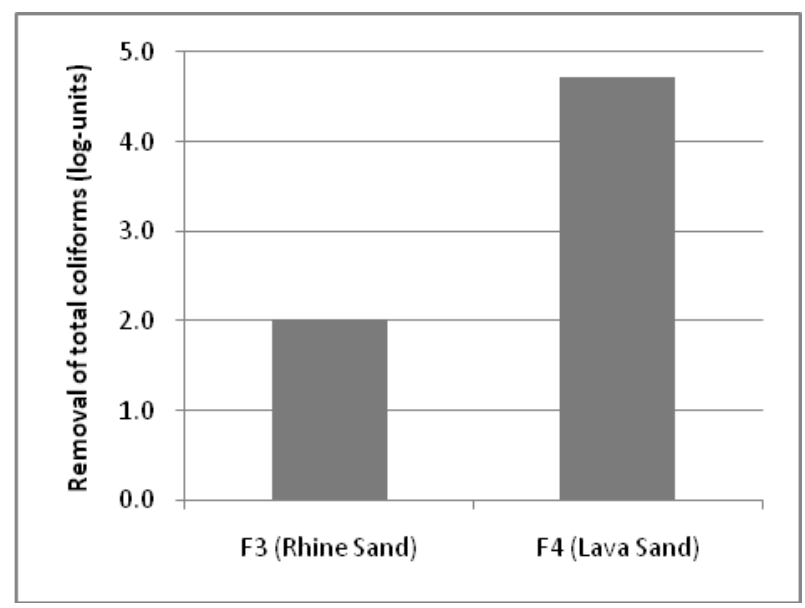

Figure 4. Removal of total coliform in configuration $\mathrm{C} 2$

As can be seen in the figures above (Figure 3 and 4), the same pattern was noticed in all comparisons. Lava sand appears to give a better result in removing both total coliforms and E. coli for both configurations. Lava sand was able to reduce the concentration of bacteria in the effluent reaching $2.5-4.7 \log$-units removal of total coliforms and $2.5-5 \log$-units removal of E. coli. Lava sand performed better than Rhine sand. It was likely caused by the different grain shape between Lava sand (angular shape) and Rhine sand (circular shape). Barton et al. (2007) stated that the more angular the sand grains, the more particles in wider range of size could be strained out in the filter. The results obtained seem to be consistent to that reported by Barton et al. (2007). The materials used have different shape, sizes, and chemical composition due to their origin. These different characteristics of materials could affect contaminant removal.

Barton et al. (2007) indicated that the interstitial straining of particles decreased as the circularity coefficient increased. The highest interstitial straining was achieved by crushed limestone and the smallest one was spherical material from the river. It showed that the angular material caught the impurities more efficiently than the rounded material thus this angular material enhanced the filter performance in removing waterborne contaminants. Moreover, Stevik et al. (1999) reported that in 
dosing rate of $25 \mathrm{~mm} /$ day, the crushed Light Weight Aggregates (LWA) performed better than the spherical LWA in reducing E. coli attained $100 \%$ and $99.999 \%$, respectively.

\section{c. Effect of influent water quality (bacteria concentration)}

The best bacteria removal was achieved by filter column F4. It was probably caused by a higher concentration of indicator bacteria in its influent water as can be seen in Table $1(20 \%$ of wastewater and $80 \%$ of tap water). This high number of bacteria seemed to improve the adsorption mechanisms that enhance bacteria removal. Stevik et al. (2004) mentioned that the increase of bacteria concentration leads to improve the collisions between bacteria and media surface and subsequently increase the likelihood of adhesion process within the media. The rate of adsorption increases linearly with the bacteria concentration (Stevik et al., 2004).

Table 1. Influent water quality

\begin{tabular}{|c|c|c|c|}
\hline Parameter & Units & Influent A & Influent D \\
\hline Total Coliforms & CFU/100ml & 931382 & 2243943 \\
\hline$E$. Coli & CFU/100ml & 391572 & 912479 \\
\hline $\mathrm{pH}$ & & 6.54 & 6.84 \\
\hline Conductivity & $\mu \mathrm{S} / \mathrm{cm}$ & 780 & 851 \\
\hline $\mathrm{O}_{2}$ & $\mathrm{mg} / \mathrm{L}$ & 8.24 & 7.78 \\
\hline Settleable solids & $\mathrm{ml} / \mathrm{L}$ & 0.1 & 1.2 \\
\hline Turbidity & $\mathrm{NTU}$ & 20 & 40 \\
\hline TOC & $\mathrm{mg} / \mathrm{L}$ & 49.9 & 61.5 \\
\hline Hardness & $\mathrm{mmol} / \mathrm{L}$ & 3.53 & 3.50 \\
\hline Filterable & $\mathrm{mg} / \mathrm{L}$ & 24.2 & 47.6 \\
\hline Loss on ignition & $\%$ & 81.0 & 84.5 \\
\hline Fe & $\mathrm{mg} / \mathrm{L}$ & 0.12 & 0.17 \\
\hline $\mathrm{Mn}$ & $\mu \mathrm{g} / \mathrm{L}$ & 7.4 & 10.7 \\
\hline $\mathrm{Mg}$ & $\mathrm{mg} / \mathrm{L}$ & 14.24 & 14.87 \\
\hline $\mathrm{Zn}$ & $\mathrm{mg} / \mathrm{L}$ & 1.90 & 2.08 \\
\hline $\mathrm{BOD}$ & $\mathrm{mg} / \mathrm{L}$ & 15.9 & 31.7 \\
\hline $\mathrm{COD}$ & $\mathrm{mg} / \mathrm{L}$ & 33.2 & 77.6 \\
\hline
\end{tabular}

Source: Institut für Wasser und Gewässerentwicklung (IWG) 50.40, Lab. 206 (June $1^{\text {st }}, 2011$ ) 


\section{CONCLUSIONS AND SUGGESTIONS}

\section{a. Conclusions}

The results of these experiments were summarized in terms of the effectiveness of bacteria removal under three configurations of grain size distributions and two different sand types which has different grain shape. From the results obtained it can be concluded as follows:

1. SSF is a reliable process to improve microbiological quality of water.

2. A smaller grain size leads to an increase in bacteria removal.

3. A higher bacteria removal was achieved by the filter columns filled with the Lava sand (angular shape) compared to that with Rhine sand (spherical shape).

4. This high number of bacteria in the influent tended to improve the adsorption mechanisms that enhance bacteria removal.

\section{b. Suggestions}

To improve the findings of this present study, some suggestions are as follows:

1. The modification of experimental setup should be carried out, i.e. using a pump in the filter outlet in order to get a more precise and constant filtration rate. Within this constant filtration rate, the results would become more reliable to be used as a basis to design a pilot plant of slow sand filtration.

2. To ascertain the same concentration of bacteria in the influent, the method of microbiological culture should be done before the experiments are carried out. This method aims to multiply microbiological organisms by growing them up in predetermined culture media under the controlled laboratory conditions. By doing so, the precise measurement of filter efficiency on bacteria removal could be attained.

3. The further experiment relating to sand properties should be conducted in order to get a trustworthy analysis in particle shape.

4. The subsequent experiments in terms of the development of biofilm or biolayer on the sand surface or within the sand bed should be carried out to assure the effect of intermittent operation to the development of biofilm or biolayer.

5. The following study should be conducted to know the clogging time or the running period of sand filter.

6. The research of slow sand filtration using local material regarding bacteria removal and turbidity should be carried out to acquire the real implementation of this study in the case area (Gunung Kidul). 
7. The chemical properties of both sand filter and raw water should be considered in the subsequent study.

8. Filter column F4 (Lava sand, $\mathrm{d} 10=0.07 \mathrm{~mm}$ and $\mathrm{Cu}=4.2$ ) performed the best bacteria removal in this experiment achieving 4.7 log-removal of total coliforms and 5.0 log-removal of E. coli. However, with this filter configuration, an excellent performance can be achieved under specific condition i.e. a HLR $0.03 \mathrm{~m} / \mathrm{h}$. According to this condition, it would be not anymore economically feasible due to the need of larger area. It is probably good as a decentralized SSF or a household SSF.

9. Filter column F5 (Rhine sand, $\mathrm{d} 10=0.2 \mathrm{~mm}$ and $\mathrm{Cu}=2.1$ ) with the configuration in the range of recommendation and HLR $0.1-0.2 \mathrm{~m} / \mathrm{h}$, performed a better bacteria removal than filter columns F1, F2, and F3. It achieved 2.7 log-removal of both total coliforms and E.coli. This filter characteristic or configuration is very good to be applied as a centralized SSF.

\section{References}

Ausland, G., Stevik, T.K., Hanssen, J.F., KØhler, J.C., Jenssen, P.D., 2002, Intermittent filtration of wastewater-removal pf fecal coliforms and fecal streptococci. Water Research 36, 35073516

Barton, J.M.H., \& Buchberger, S.G., 2007, Effect of media grain shape on particle straining during filtration, Journal of Environmental Engineering, Vol. 133, No. 2

Bellamy, W.D., Silverman, G.P., Hendricks, D.W., \& Logsdon, G.S., 1985a, Removing Giardia Cysts with Slow Sand Filtration. American Water Works Association, 77(2), 52-60

Bellamy, W.D., Hendricks, D.W., \& Logsdon, G.S. 1985b., Slow Sand Filtration: Influences of Selected Process Variables, American Water Works Association, 77(12), 62-66

Haryono, E., \& Day, M. 2004. Landform differentiation within the Gunung Kidul Kegelkarst, Java, Indonesia, WasserWirtschaft, 66(2), 62-69

Langenbach, K., Kuschk, P., Horn, H., Kastner, M., 2009, Slow sand filtration of secondary clarifier effluent for wastewater reuse. Environmental Science and Technology, 43, 5896-5901

Nestmann, F., Oberle, P., Ikhwan, M., Klingel, P., Stoffel, D., Solichin, 2011, Development of underground hydropower systems for karst area - Pilot study Java, Indonesia. Asian TransDisciplinary Karst Conference. Indonesia 
Stevik, T. K., Aa, K., Ausland, G., Hanssen, J. F., 2004, Retention and removal of pathogenic bacteria in wastewater percolating through porous media: a review. Water Research 38, $1355-1367$

Stevik, T. K., Aa, K., Ausland, G., Jenssen, P.D., \& Siegrist, R.L., 1999, Removal of E. Coli during intermittent Filtration of wastewater effluent as affected by dosing rate and media type. Water Research Vol. 33, No. 9, 2088-2098

WHO, World Health Organization, \& UNICEF, The United Nations Children's Fund, 2010, Progress on Sanitation and Drinking Water - 2010 Update. World Health Organization and UNICEF Joint Monitoring Programme for Water Supply and Sanitation. France 